\title{
KRŪTIES KARCINOMOS METASTAZE் ŠVIESIALĄSTELINĖJE INKSTO LĄSTELIŲ KARCINOMOJE: KLINIKINIS ATVEJIS
}

\author{
Ilja Rudoj \\ Klaipédos universitetine ligoniné
}

\author{
Raktažodžiai: krūties karcinoma, inksto karcinoma, \\ metastaze „navikas ị naviką“.
}

\section{Santrauka}

Navikų metastazavimas ị kitus navikus (tumor-to-tumor metastasis /TTM) - labai retas fenomenas. Šiame straipsnyje pristatomas krūties karcinomos metastazavimo ị šviesialąstelinę inksto ląstelių karcinomą atvejis. 69 metų pacientei, daugiau nei 10 metų sergančiai krūties karcinoma, ịtartas ligos progresavimas ị inkstus. Ligos židiniui pašalinti atlikta nefrektomija. Atliekant patologijos tyrimą, inkste nustatyta $4 \mathrm{~cm}$ skersmens šviesialąstelinè inksto ląstelių karcinoma, kurioje buvo aptikta 2,9 mm krūties karcinomos metastazè. Krūties karcinoma labai retai metastazuoja ị inkstus, literatūroje aprašyta tik 15 tokių atvejų. Krūties karcinomos metastazès ị inkstų ląstelių karcinomą yra labiausiai paplitęs naviko metastazių ị kitus navikus variantas. Literatūroje aprašyti 9 panašūs atvejai.

Straipsnio tikslas - pristatyti retą patologinès diagnostikos atvejị, parodžiusị, jog esant dauginiams navikų židiniams, būtina atlikti jų histologinị ištyrimą. Sinchroninių ir metachroninių navikų ir metastazių atpažinimas daro įtaką pacientų gydymui ir prognozei. Naviko metastazavimo ị kitą naviką fenomeno mokslinis tyrimas gali suteikti naujos informacijos apie navikų biologiją, padèti kurti naujus diagnostikos, gydymo ir prevencijos metodus.

\section{Ivadas}

Sinchroniniai navikai vienam pacientui pasireiškia apie 8 proc. atvejų, tačiau naviko metastazavimas ị kitą naviką pasitaiko žymiai rečiau. Literatūroje aprašyta apie 50 panašaus pobūdžio atvejų. Šis straipsnis apie krūties karcinomos metastazavimą į šviesialąstelinę inksto ląstelių karcinomą. Kiek žinoma, literatūroje aprašyti 9 panašūs atvejai (2 lentelè). Krūties karcinoma yra labiausiai paplitęs moterų piktybinis navikas. Šviesialąstelinè inksto ląstelių karcinoma yra labiausiai paplitęs sinchroninis ir metachroninis navikas dauginių navikų atvejais ir dažniausias kitų navikų metastazių recipientas.

Darbo tikslas - pristatyti retą naviko metastazavimo i kitą naviką (tumor-to-tumor metastasis /TTM) diagnostini atveji ir pateikti susijusios literatūros apžvalgą, parodant, jog atsiradus naujų naviko židinių, būtina jų histologinè diferencine diagnostika, nes metastazių atpažinimas turi įtakos pacientų gydymui ir prognozei.

\section{Klinikinis atvejis}

69 metų moteriai, sirgusiai krūties karcinoma, buvo ịtartas ligos progresavimas. Anamnezèje pacientei prieš 10 metu (2011.07.21) kairèje krūtyje diagnozuotas 2,5 cm darinys (biopsijoje - krūties duktalinè karcinoma); 2012.01 .30 atlikta radikali mastektomija (patologijos diagnozè - infiltracinè duktalinè kairès krūties karcinoma, pT2, N3b, Mx, G3, R0). Praejjus 10 metu po pirminès diagnozès nustatymo ir pirminio naviko pašalinimo, pastebètas ligos progresavimas - karcinomos metastazès pleuroje ir tarpuplautyje. Pirminio naviko ir metastazių estrogenu, progesterono receptorių, Ki67 proliferecinio aktyvumo ir HER2 receptorių imunihistocheminio tyrimo duomenys pateikti (1 lenteleje). Profilaktinio tyrimo metu įtarus krūties karcinomos metastazę kairiajame inkste, pacientei buvo atlikta nefrektomija (2021.04.09).

Patologinio tyrimo metu inksto apatiniame poliuje aptiktas $\sim 4 \mathrm{~cm}$ skersmens gelsvai rudas, mazguotas navikas su kraujo išsiliejimais. Tai ịprastas makroskopinis vaizdas, būdingas šviesialąstelinei inksto ląstelių karcinomai.

Mikroskopinio tyrimo metu tarp šviesialąstelinès inksto ląstelių karcinomos struktūrų (lizdai ir acininès struktūros, formuojamos iš atipinių ląstelių gausia, šviesia citoplazma ir nežymiai polimorfiškais, ovaliais branduoliais) buvo aptiktas ribotas $2,9 \mathrm{~mm}$ židinys, bendrame fone išsiskiriantis kitokia struktūra. Židinị formavo lizdai ir trabekulès atipinių ląstelių su eozinofiline citoplazma ir ovaliais, nežymiai polimorfiškais branduoliais. Imunohistocheminis tyrimas, naudojant imunožymenis RCC, CA-IX, PAX-8, CK7, GATA-3, ER 
ir PR antikūnus (1 pav.), irodè, kad anomalinis židinys yra krūties karcinomos metastazè, visiškai apsupta inksto ląstelių karcinomos. Metastazès estrogenų, progesterono receptorių, Ki67 proliferecinio aktyvumo ir HER2 receptorių imunihistocheminio tyrimo duomenys pateikti (1 lenteleje). Patologinio tyrimo išvada - šviesialąstelinè inksto ląstelių karcinoma (Furhman I), pT3a, N0, M0, G1, su intravaskuliniu plitimu inksto vartų venoje. Krūties duktalinès karcinomos metastazè šviesialąstelinèje inksto ląstelių karcinomoje. Inksto karcinoma ir metastazè pašalintos radikaliai.

\section{Diskusija}

Nors per inkstus prateka apie 20 proc. kraujo minutinio tūrio, metastazès inkstuose labai retas reiškinys. Kalbant apie įvairių navikų metastazavimo ị inkstus dažnį, plaučių navikai yra pirmoje vietoje, o krūties - antroje [2]. Krūties karcinomos metastazavimo ị inkstus dažnis išskirtinai mažas. Literatūroje minima tik 15 nepriklausomų atvejų [4]. Pacientui, sergančiam krūties karcinoma, yra maždaug 2-3 proc. tikimybe susirgti kitu sinchroniniu ar metachroniniu naviku [3]. Ir būtent inksto ląstelių karcinoma aprašoma, kaip dažniausias sinchroninis arba metachroninis navikas, kuris išsivysto sergant krūties karcinoma. Apie 16-27 proc. pacientų, sergančių inksto karcinoma, gali turèti ir kitų navikų.

Navikų metastazavimas į kitus navikus (angl.tumor-totumor metastasis /TTM) yra dar retesnis fenomenas. Iki šiol aprašyta tik apie 50 tokių atvejų. Patys dažniausi metastazių recipientai yra inksto ląstelių karcinomos. Jos apima apie 65 proc. aprašytų atvejų [1]. Po jų - sarkomos, meningiomos, skydliaukès ir hipofizès navikai. Dažniausi metastazių dono-
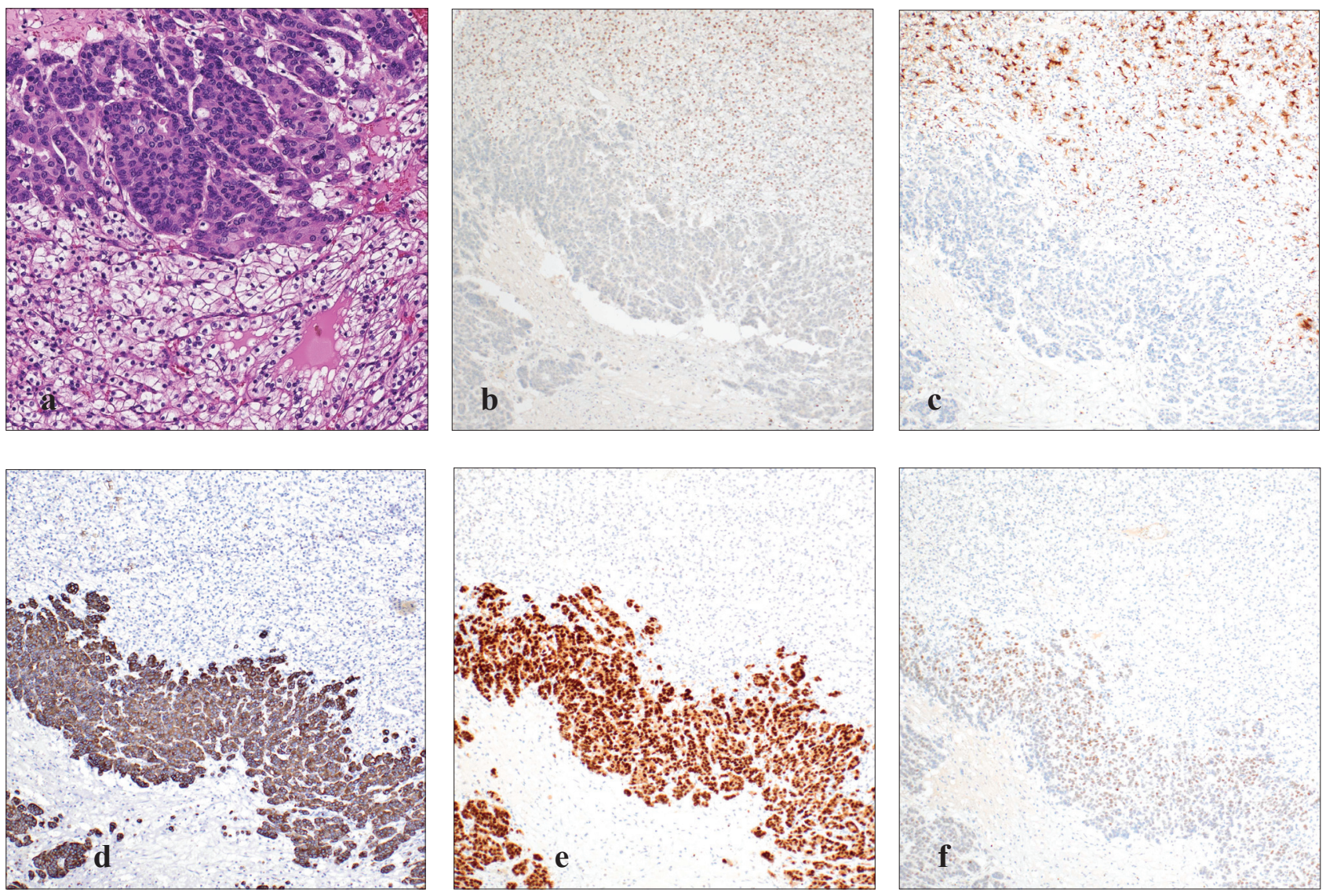

1 pav. Krūties duktalinès karcinomos metastazių šviesialąstelinèje inksto ląstelių karcinomoje histologiniai vaizdai:

a) krūties duktalinès karcinomos metastazè (viršuje) inksto šviesialąstelinèje karcinomoje (apačioje). HE;

b) teigiama PAX8 imunohistocheminè reakcija inksto šviesialąstelinèje karcinomoje;

c) teigiama RCC imunohistocheminè reakcija inksto šviesialastelinejje karcinomoje;

d) teigiama CK7 imunohistocheminè reakcija krūties karcinomoje;

e) teigiama GATA3 imunohistochemine reakcija krūties karcinomos metastazèje;

f) teigiama ER imunohistocheminè reakcija krūties karcinomos metastazeje. 
rai - plaučių, krūties, prostatos ir skydliaukès karcinomos.

Pirmą TTM atvejị aprašè W. Berent 1902 metais [6,17].

TTM diagnozei būtinų kriterijų atitikimą aprašè L.V. Campbell 1968 metais [7]. Pirma, pacientui turi būti du ar daugiau skirtingų navikų, o navikas recipientas turi būti tikroji gerybinè arba piktybinè neoplazija. Antra, metastazinis navikas turi būti tikroji metastazè, o ne įaugimas (angl. collision tumor).

1 lentelė. Estrogenų, progesterono receptorių, Ki67 proliferacinio aktyvumo ir HER2 receptorių imunihistocheminio tyrimo duomenys.

ER estrogenu receptoriai; PR progesterono receptoriai; HER2 žmogaus epidermio augimo faktoriaus receptorius 2; Ki67 proliferacinis žyтио; N/A nèra informacijos

\begin{tabular}{|l|c|c|c|c|c|}
\hline Medžiaga & $\begin{array}{c}\text { ER (pagal } \\
\text { Allred } \\
\text { schemą) }\end{array}$ & $\begin{array}{c}\text { PR (pa- } \\
\text { gal Allred } \\
\text { schemą) }\end{array}$ & Ki67 & HER2 IHC & HER2 FISH \\
\hline Pirminė biopsija & $8 / 8$ & $1 / 8$ & $\mathrm{~N} / \mathrm{A}$ & +1 & - \\
\hline Mastektomija & $6 / 8$ & $\mathrm{~N} / \mathrm{A}$ & $10 \%$ & +1 & - \\
\hline Metastazė pleuroje & $8 / 8$ & $\mathrm{~N} / \mathrm{A}$ & $\mathrm{N} / \mathrm{A}$ & $\mathrm{N} / \mathrm{A}$ & - \\
\hline Metastazė tarpuplautyje & $7 / 8$ & $0 / 8$ & $7 \%$ & +1 & - \\
\hline Metastazė inksto karcinomoje & $8 / 8$ & $0 / 8$ & $2-3 \%$ & +2 & neigiamas \\
\hline
\end{tabular}

2 lentelè. Krūties karcinomos metastazavimo ị šviesialąstelinę inksto ląstelių karcinomą atvejų apžvalga.

$C$-M intervalas - intervalas tarp krüties karcinomos diagnozés ir metastazés i $R C C$; * diagnozé nustatyta po autopsijos; ** su neuroendokrinine diferenciacija; G diferenciacijos laipsnis; ER estrogenu receptoriai; PR progesterono receptoriai; HER2 žmogaus epidermio augimo faktoriaus receptorius 2; Ki67 proliferacinis žymuo; RCC šviesialasteline inksto lasteliu karcinoma (angl. renal cell carcinoma); + teigiamas; - neigiamas; No be papildomos informacijos.

\begin{tabular}{|c|c|c|c|c|c|c|c|c|c|c|}
\hline \multirow[t]{2}{*}{ Autorius } & \multirow{2}{*}{$\begin{array}{l}\text { C-M in- } \\
\text { tervalas } \\
\text { (metai) }\end{array}$} & \multirow{2}{*}{$\begin{array}{l}\text { Amžius } \\
\text { (metai) }\end{array}$} & \multicolumn{7}{|c|}{ Krūties karcinoma } & \multirow{2}{*}{$\begin{array}{c}\text { Metastazių } \\
\text { vieta }\end{array}$} \\
\hline & & & tipas & TNM & $\mathrm{G}$ & ER & PR & HER2 & Ki67 & \\
\hline Sella A*[1] & 1 & 62 & Duktalinè & $\mathrm{T} 2 \mathrm{~N} 2 \mathrm{M} 0$ & No & No & No & No & No & $\begin{array}{l}\text { RCC kepe- } \\
\text { nys blužnis } \\
\text { plaučiai kau- } \\
\text { lai }\end{array}$ \\
\hline Val-Bernal* [11] & 30 & 75 & Duktalinè & T2N0M0 & No & - & - & + & No & $\begin{array}{l}\text { RCC pleura } \\
\text { perikardas } \\
\text { pilvaplèvè } \\
\text { plaučiai kau- } \\
\text { lai }\end{array}$ \\
\hline $\begin{array}{l}\text { Begara Morillas } \\
\text { et al. [12] }\end{array}$ & 4 & 50 & No & No & No & No & No & No & No & RCC kaulai \\
\hline $\begin{array}{l}\text { Van Wynsberge et al. } \\
{[13]}\end{array}$ & 6 & 64 & Duktalinė & T3N1M0 & 2 & - & - & No & No & $\begin{array}{l}\text { RCC plaučiai } \\
\text { kepenys kau- } \\
\text { lai }\end{array}$ \\
\hline Möller et al. [14] & 2 & 62 & Duktalinė & T4N3M0 & 3 & + & + & - & No & $\begin{array}{l}\text { RCC pleura } \\
\text { viršugalvis }\end{array}$ \\
\hline Huo et al. [6] & 4 & 43 & Duktalinè & T2N0M1 & No & + & + & - & $20 \%$ & $\begin{array}{l}\text { RCC kepenys } \\
\text { tarpuplautis }\end{array}$ \\
\hline Ulamec et al. [15] & 0 & 60 & $\begin{array}{c}\text { Duktaliné } \\
\qquad * *\end{array}$ & T4N2M1 & 3 & + & + & - & $22 \%$ & $\mathrm{RCC}$ \\
\hline Perrin et al. [16] & 0 & 49 & Duktalinè & T4N1M1 & 3 & - & - & - & No & $\begin{array}{l}\text { RCC plau- } \\
\text { čiai kaulai }\end{array}$ \\
\hline \multirow[t]{2}{*}{ Lakovschek et al. [3] } & \multirow[t]{2}{*}{0} & \multirow[t]{2}{*}{79} & \multirow[t]{2}{*}{$\begin{array}{l}\text { Duktalinè } \\
\text { bilaterali }\end{array}$} & $\begin{array}{l}\text { Dešinè: } \\
\text { T2N3M1 }\end{array}$ & 3 & + & + & + & $80 \%$ & \multirow[t]{2}{*}{ RCC kaulai } \\
\hline & & & & $\begin{array}{c}\text { Kairè: } \\
\text { T2N0M1 }\end{array}$ & 2 & + & + & + & $70 \%$ & \\
\hline Dabartinis atvejis & 10 & 69 & Duktalinè & T2N3bM0 & 3 & + & - & - & $10 \%$ & $\begin{array}{l}\mathrm{RCC} \text { pleura } \\
\text { tarpuplautis }\end{array}$ \\
\hline
\end{tabular}


Papildomas kriterijus: metastazè turi būti suderinama su pirminiu naviku morfologiškai ir imunohistochemiškai.

Mūsų atvejis visiškai atitinka visus kriterijus.

Istoriškai dvi hipotezès bando paaiškinti TTM mechanizmą [6]. „Sèklos ir dirvos“ (angl. seed and soil) teorija numato tinkamos mikroaplinkos (dirvos) buvimą sékmingai metastazès (sèklos) implantacijai ir vystymuisi. „Mechaniné“ teorija paaiškina filtracijos procesą aukštos kraujotakos sąlygomis. Daroma prielaida, jog navikai recipientai yra imlūs metastazèms dèl jų intensyvios kraujotakos, gausios vaskuliarizacijos ir anatominès lokalizacijos. Naviko donoro ląstelès su kraujo srove teka pro naviką recipientą, filtruojamos įstringa ir lieka jame.

Gera inksto ląstelių karcinomų vaskuliarizacija, aukštas glikogeno ir lipidų kiekis visiškai suderinami su abiem teorijomis. Dabartiniai tyrimai rodo, kad metastazavimas gali būti aktyvus procesas, kurio metu pirminis navikas pasirengia metastazavimo nišą [9]. Galima įtarti, kad yra ypatingieji faktoriai ir mechanizmai, sukeliantys santykinai dažną krūties karcinomos metastazavimą ị inksto ląstelių karcinomą.

Analizuotoje literatūroje paminèti 9 tokių metastazių atvejai ( 2 lentelè). Dabartinis atvejis yra 1 iš 7 su metachroniniu metastazavimu. Tai atvejis su ilgiausiu intervalu tarp pirminio naviko ir metastazès diagnozavimo, nustatytas pacientei dar esant gyvai. Visais pristatomais atvejais metastazavo krūties duktalinė karcinoma. Estrogenų, progesterono ir HER2 receptorių būklè yra labai ịvairi, linkusi ị ER + / HER2 - fenotipą. Visais atvejais krūties karcinoma mastektomijos metu turejo vietinių ir (arba) tolimesnių metastazių.

\section{Išvados}

1. Navikų metastazavimo ị kitus navikus tikimybe didejja kartu su ligos stadija. Pažengusiame piktybinio proceso etape esant dauginių naviko židinių, būtina atlikti jų biopsiją arba eksciziją ir histologinę diferencinę diagnostiką. Sinchroninių ir metachroninių navikų ir metastazių atpažinimas turi ịtakos pacientu gydymui ir prognozei.

2. Šio fenomeno mokslinis tyrimas gali suteikti naujos informacijos apie navikų biologiją, padèti kurti naujus diagnostikos, gydymo ir prevencijos metodus.

\section{Literatūra}

1. Sella A, Ro JY.Renal cell cancer: Best recipient of tumor-totumormetastasis. Urology 1987;30(1):35-8. https://doi.org/10.1016/0090-4295(87)90568-1

2. Angela J Wu et al. Metastases to the kidney: a clinicopathological study of 43 cases with an emphasis on deceptive features. Histopathology 2015;66:587-597. https://doi.org/10.1111/his.12524

3. Lakovschek IC, Petru E, Pollheimer MJ, Ratschek M, Augustin
H, Bjelic-Radisic V. A rare case of cancer-to-cancer metastasis: breast cancer to renal cell cancer. Wien Med Wochenschr 2019; 169:350-353.

https://doi.org/10.1007/s10354-019-0694-y

4. Gilbert B. et al. Metastatic breast cancer masquerading as a renal malignancy: A literature review and case report. Urology Case Reports 24(2019)100859.

https://doi.org/10.1016/j.eucr.2019.100859

5. Zhou C. et al. Metastases to the Kidney: A Comprehensive Analysis of 151 Patients from a Tertiary Referral Center. BJU Int 2016May;117(5):775-782.

https://doi.org/10.1111/bju.13194

6. Huo Z. et al. Metastasis of breast cancer to renal cancer: report of a rare case. Int J Clin Exp Pathol 2015;8(11):15417-15421. www.ijcep.com/ISSN:1936-2625/IJCEP0016092

7. Campbell LV, Gilbert E. Metastases of cancer to cancer. Cancer 1968;22:635-643.

https://doi.org/10.1002/1097-0142(196809)22:3<635::AIDCNCR2820220320>3.0.CO;2-O

8. Rabbani F, Reuter VE, Katz J, RussoP. Second primary malignancies associated with renal cell carcinoma: Influence of histologictype. Urology 2000;56(3):399-403.

https://doi.org/10.1016/S0090-4295(00)00682-8

9. Thomas R. Cox et al. The hypoxic cancer secretome induces pre-metastatic bone lesions through lysyl oxidase. Nature 2015;522:106-110.

https://doi.org/10.1038/nature14492

10. Petraki $C$ et al. Tumor to tumor metastasis: Report of two cases and review of the literature. Int J Surg Pathol 2003;11:127-135. https://doi.org/10.1177/106689690301100214

11. Val-Bernal JF, Villoria F, Pérez-Expósito MA.Concurrent angiomyolipomas and renal cell carcinoma harboring metastatic foci of mammary carcinoma in the same kidney: an incidental autopsy finding in a patient with a follow- up of thirty years. Ann Diagn Pathol 2001;5:293-9.

https://doi.org/10.1053/adpa.2001.27920

12. Begara Morillas F, Silmi Moyano A, Rapariz González M, Esteban Fuertes M, Blanco González J, Chicharro Molero J, et al. Renal metastasis from breast carcinoma: A new case and review of the literature. Arch Esp Urol 1995;48(2):199-203.

13. Van Wynsberge LK, Vierling P, Lampel A. Breast cancer metastatic to a renal cell carcinoma. Aktuelle Urol 2004;35(6):505-7. https://doi.org/10.1055/s-2004-818528

14. Möller MG, Gribbin T, Ebrom S, Padula G, Fitzgerald TL. Breast cancer metastatic to renal cell carcinoma. Surgery 2006;139(4):577-9.

https://doi.org/10.1016/j.surg.2005.10.016

15. Ulamec M, Tomas D, Peri'c-Balja M, Spaji'c B,Hes O,Krušlin B. Neuroendocrine breast carcinoma metastatic to renal cell carcinoma and ipsilateral adrenal gland. Pathol Res Pract 2008;204(11):851-5. 
https://doi.org/10.1016/j.prp.2008.04.006

16. Perrin C, Talarmin M, Fontaine A, Kerbrat P, Audrain O, RiouxLeclercq N, et al. Breast carcinoma metastasis into a renal cell carcinoma. Ann Pathol 2011;31(5):399-401.

https://doi.org/10.1016/j.annpat.2011.06.007

17. Berent W. Seltene metastasenbildung. Zentralbl Allg Pathol 1902;13:406-410.

\section{METASTASIS OF BREAST CARCINOMA IN CLEAR CELL RENAL CELL CARCINOMA: A CASE REPORT \\ I. Rudoj}

Keywords: Breast carcinoma; Renal cell carcinoma; Tumorto-Tumor metastasis.

Summary

Tumor to tumor metastasis (TTM) is very rare. This article presents a case of metastasis of breast carcinoma to clear cell renal cell carcinoma of the kidney. A 69 -year-old patient with a 10-year history of breast cancer was suspected of this cancer progression to the kidney. A nephrectomy was performed to remove the lesion. Pathological investigation of the kidney revealed a clear cell re- nal cell carcinoma with a diameter of $4 \mathrm{~cm}$, in which metastasis of breast carcinoma $2.9 \mathrm{~mm}$ was found. Breast cancer very rarely metastasizes to the kidneys. Only 15 cases are described in the literature. However, metastasis of breast carcinoma to renal cell carcinoma is the most common variant of tumor metastasis to other tumors, with 9 descriptions in the literature.

The purpose of this article is to present a rare pathological diagnostic case and indicate that in the case of multiple tumor foci, their biopsy and histological diagnosis are necessary.

Recognition of synchronous and metachronous tumors and metastases influences the treatment and prognosis of patients.

The study of the phenomenon of tumor metastasis to another tumor can provide new information about the biology of tumors, help in the development of new methods of diagnosis, treatment and prevention.

Correspondence to: iljarudy@gmail.com

Gauta 2021-09-29 